conservator of forests, Bombay; Miss U. F. M. Morton, principal, Women's Medical School, Agra, United Provinces; Mr. K. R. N. Pillai, extra assistant conservator of forests, Jubbulpore, Central Provinces and Berar; Mr. H. G. Smith, statistician, Agricultural Department, Uganda Protectorate. I.S.O. : Mr. J. M. Dunbar, assistant and office superintendent, Department of Agriculture, Gold Coast.

\section{Dr. George Senter}

Dr. George Senter, principal of Birkbeck College, University of London, since 1918, retires at the end of the current session. He became head of the Department of Chemistry at the College in 1914 and retained that position until 1932. His principalship has been a memorable one. In 1920 the College was recognized as a school of the University of London and in 1926 a Royal Charter was granted. The College thereby realized an ambition which existed so far back as 1863, when courses of instruction for University of London examinations were instituted. Further, Principal Senter has played a major part in the elaboration of the scheme for new buildings which are to be erected on the University site at Bloomsbury. His sound judgment and wide administrative experience have been of the greatest value in University affairs. Principal Senter first became a member of the Senate in 1912, was for many years chairman of the University Extension and Tutorial Classes Council and chairman of the University Scholarships Committee, and held the office of deputy vice-chancellor in 1933-34. To this record of distinguished service must be added the profound influence which Dr. Senter has exerted as investi. gator, teacher and writer in the realm of chemistry. He has contributed many important communications to scientific journals on physico-chemical and biochemical subjects and his "Outlines of Physical Chemistry" (17th Edition, 1933) and "Text Book of Inorganic Chemistry" (14th Edition, 1934) bear witness to his distinction as a writer and teacher. Recently the staff of Birkbeck College made a presentation to Principal Senter, which in the words of Prof. Dame Helen Gwynne-Vaughan, the chairman on that occasion, "will be a frequent reminder of the affectionate regard--the enduring respect-of those with whom he has worked so long".

\section{The late Prof. E. B. Wilson, For.Mem.R.S.}

Referring to Prof. E. W. MacBride's obituary article on Prof. E. B. Wilson in Nature of April 1 "a gracious appreciation of the work of an eminent fellow biologist", Prof. G. N. Calkins and Prof. J. H. McGregor write that the statement that "His illhealth and subsequent death were due to a tragic accident which befell him when he was conducting a body of students, men and women, on a cruise up the Pacific coast of Canada" is incorrect. On the return journey the boat struck a rock and foundered. They write that they were members of the Columbia University party referred to and have been closely associated with Prof. Wilson ever since until his death. It is true that the ship struck a submerged rock and sank, but no one suffered the slightest physical injury and no one was in the water. The sea was calm, there was no panic, the transfer of passengers and crew to the lifeboats was conducted in an orderly manner and more than two hours elapsed after striking the rock before the ship finally disappeared. This occurred on August 5, 1897. By far the greater part of Wilson's cytological research and much of his work in experimental embryology were done after the shipwreck. His last contribution to cellular biology was published in 1937, when he was eighty years of age, and his last visit to the laboratory was one week before his death.

\section{Colonial Administration and Progress, I938-39}

IF a certain complacency noted by critics was not indeed entirely absent from Mr. Malcolm MacDonald's review of the year's activities in the debate in the House of Commons on June 7 on the estimates for Colonial and Middle Eastern Services, 1939, he no doubt derived justification from the substantial progress made. Further, the increased interest and understanding of Colonial problems on the part of the public warranted a certain optimism in forecasting increased activity on the part of the administrative authorities in applying the resources of scientific research to the solution of the varied problems which have arisen, especially in Africa, from the contact of backward peoples with the, to them, new standards of a more advanced civilization. Among the more notable features, indeed, of a statement which as a whole can in truth be described as gratifying, was Mr. MacDonald's announcement of the consideration being given, both by the local administrative authorities and the Colonial Office in London, to the recommendations of Lord Hailey's "African Survey" and of Lord Bledisloe's Rhodesia-Nyasaland Commission, and especially to the manner in which effect can be given to the main proposal of the former for the development and co-ordination of research. In dealing with the varied range of problems with which research in Africa is now concerned, Mr. MacDonald was able to speak only in most general terms; but this was of less moment as the annual report was already available ("The Colonial Empire : Statement relating to the Period 1st April, 1938 to 31st March, 1939, to accompany the Estimates for Colonial and Middle Eastern Services, 1939". H.M. Stationery Office. Pp. iv +97 . 1s. 6 d. net), in which the activities of administration are set out in detail under headings such as "Research", "Social Progress", "Development of Natural Resources" and the like.

IN opening his statement, Mr. MacDonald emphasized the responsibility of British democracy in government of the Colonial Empire-a field, as he said, of every kind of variety in which "we were still to a greater or less degree the trustees, the guardians, and the tutors of the various peoples". As was said by Sir Edward Grigg on another occasion a few days later, criticism of our ability to make the best for all men of the vast territories under our control is a moral challenge which is by far the most 
serious we have to repel. In Africa, which at present is our gravest responsibility, the touchstone of our policy, whatever efforts may be expended in social or economic advancement, must be the opportunities afforded the native by our administrative system to train himself towards adjustment with the changed conditions which must result inevitably from the impact on tribal institutions of a system and civilization in which personal responsibility and personal liberty of thought and action, with certain recognized and admitted limitations due to the rights of others, are the corner-stone. Under the present administration of the Colonial Office, faith is implicit in indirect rule, or local government by traditional chiefs and native councils. The report records with a note of enthusiasm that while local government is regarded as a great experiment, "the year under review affords encouragement for continuing that experiment in high hope of success". The number of local adminis. trations has been increased in several of the African colonies; but is there a subdued note of cynicism in the remark of one of them, that under its administration, extensions "tend rather towards improving the native tribunals than towards setting up native treasuries"?

\section{Down House}

IT is just ten years ago since the British Association threw open to the public Down House, Charles Darwin's home, at Downe in Kent, which had been presented to it by Sir Buckston Browne as a memorial to be held in custody for the nation. The memorial rooms and the grounds are open without charge throughout the year except on Christmas Day, and the number of visitors during the past year is stated to have been 7,362 . This figure is very close to the average annual attendance of 7,300 during the ten years since the opening, and since the village of Downe, four miles from a railway station and on an infrequent omnibus service, is probably less easily accessible than almost any other place within the radius of twenty miles from London, it cannot be feit that the number of those who make the pilgrimage to Darwin's house is unworthy of his memory. It has, in fact, always exceeded the expectations of those who are responsible for the maintenance of the house. The collection of Darwinian relics, remarkably complete from the first, is still receiving additions from time to time. The British Association, by means of an appeal to its members and others, is now acquiring the nucleus of a collection of books, magazine articles, and other studies and critiques of Darwin's views, such as appeared in large numbers especially after the publication of the "Origin of Species" in 1859. The Association will gratefully acknowledge any appropriate gifts to the collection.

\section{An Oxford Expedition to Peru}

Three members of the Geology Department of the University of Oxford, Dr. J. V. Harrison (Christ Church), Mr. J. D. Weir (University College), and Mr. C. H. Kearny (Queen's College) and Mr. M. H. Donald are leaving on June 17 for Peru to study and map the geology of a part of the Central Andes of Peru, a triangular area the apices of which are Tarma, Cerro de Pasco, and Canta, the centre being about eighty miles north-east of Lima. Besides doing the work of mapping and survey, the expedition will collect fossils and specimens of rocks from this region for the British Museum. Dr. Harrison has a wide knowledge of Peru. Mr. Weir, a Rhodes scholar from the University of Saskatoon, has served two summers with the Canadian Geological Survey and Mr. Kearny, a Rhodes scholar from Princeton, has collected archæological material in north-western Mexico. Mr. Donald of Cumberland has previously collected for the British Museum. How much this expedition will do depends largely upon the weather it experiences. In the high altitudes where it will be, the weather in August and September is capricious and may be very stormy. The plans have been approved by the Royal Geographical Society. The expedition hopes to return to Oxford in October.

\section{Accessions to the British Museum (Bloomsbury)}

A sERIous gap in the archæological material available for study in museum collections in Great Britain has been filled by accessions to the British Museum (Bloomsbury) reported at the meeting of the Trustees held on June 10. Representative specimens have been received of the antiquities found at MohenjoDaro in the Indus Valley during the years 1925-28 in the archæological excavations carried out under Sir John Marshall, formerly Director of Archæology in India. The collection consists of 247 pieces, which have been acquired by exchange from the Director General of Archæology in India. It is of especial value to archæologists not only on account of the fact that the Indus Valley civilization, one of the major archæological discoveries of the decade following the Great War, was almost completely unrepresented previously in English museum collections, but also because of the extent to which it throws light on the relations between this civilization and that of Mesopotamia in the course of the third millennium B.C. The list of accessions to the Museum also included a remarkable archaic Sumerian figure of a seated mountain goat in gold, about $1 \frac{1}{2}$ inches long, which has been given by Mr. J. A. Spranger. It is dated approximately at about 2500 B.c. Roughly it is contemporary with, though larger than, similar objects found at Ur by Sir Leonard Woolley. From Mr. M. E. L. Mallowan's excavations in northern Syria of last year come a group of Chalcolithic pottery from the Balikh Valley and antiquities from Brak, among which are the remarkable series of amulets, seals and necklaces of beads and coloured stones, as well as the frieze from the pedestal of the statue found in a sanctuary, consisting of rows of different coloured stones or artificial material, fixed at top and bottom with gold bands and gold nails. It is dated approximately at 3000 B.c. A gold figure of a weather god of Hittite origin from Anatolia, dating from the fourteenth or thirteenth century B.c., was acquired by purchase. 